2017-11

\title{
Should lip dosing be reconsidered when performing open food challenges?
}

\author{
Venter, C
}

http://hdl.handle.net/10026.1/11480

10.1111/pai.12765

Pediatric Allergy and Immunology

Wiley

All content in PEARL is protected by copyright law. Author manuscripts are made available in accordance with publisher policies. Please cite only the published version using the details provided on the item record or document. In the absence of an open licence (e.g. Creative Commons), permissions for further reuse of content should be sought from the publisher or author. 
1 Title: Should lip dosing be reconsidered when performing open food challenges?

2 Authors: Carina Venter ${ }^{1,2,3}$, Kate Maslin ${ }^{1,2}$, Jane Grundy ${ }^{2}$, Gillian Glasbey ${ }^{2}$ \& Tara Dean ${ }^{1,2}$

3 Author affiliations:

4

5 1. School of Health Sciences and Social Work, University of Portsmouth, UK.

6 2. David Hide Asthma and Allergy Centre, St. Mary's Hospital, Isle of Wight, UK.

$7 \quad 3$. Section of Allergy and Immunology, Colorado Children's Hospital, USA.

9 Running title: "Should we revisit lip dosing again?"

10 Corresponding author:

11

12 Carina Venter

13 Section of Allergy and Immunology

14 University of Colorado Denver School of Medicine

15 Colorado Children's Hospital

16 Box B518

1713123 East $16^{\text {th }}$ Avenue, Anschutz Medical Campus,

18 Aurora, CO 80445, USA.

19 carina.venter@childrenscolorado.org

20 Tel: (720) 777-0619

21

22 Word Count: 1517

23 Number of tables \& Figures: 1 table and 1 figure.

24 Key words: Diagnosis, food allergy, lip dose, labial challenge

25 
To the Editor,

A lip dose or labial food challenge (LFC) is a simple, easy to perform method of diagnosis that could potentially be a convenient alternative to conducting an oral food challenge in children (1). Rance and Dutau (1) published a paper on LFC in 1997 demonstrating their clinical utility, according to the technique described by Moneret-Vautrin et al. (2). This involved a drop of the allergen being placed on the lower lip and left for 10 seconds to two minutes, with the mouth slightly opened. However, in the study by Rance et al. (1), children with positive LFC did not continue to have an oral food challenge (OFC). A subsequent study by Cantani et al.(3) concluded that the LFC should not replace the OFC, but be used at the first step in a food challenge, particularly where there is a risk of anaphylaxis (4). LFCs are not currently included in international food challenge guidelines (5) (7). Here we present data from lip dose reactions in the Food Allergy and Intolerance (FAIR) study from the Isle of Wight in the United Kingdom (UK), with the aim of demonstrating the predictive value of LFCs for diagnosis of food allergy, compared to OFCs.

\section{Methodology}

The FAIR study comprised of two different types of cohorts: The FAIR birth cohort $(n=969)$ which was seen and challenged at 1,2, 3, and 10/11 years of age (7-9). The FAIR school cohorts included 3 cohorts of children aged 6,11 and 15 years $(n=798,775$ and 757 respectively) $(8,11)$. In the FAIR birth cohort, 900 (92.9\%), 858 (88.5\%), 891 (92.0\%) and 827 (85.4\%) children were seen at 1, 2, 3, and 10/11 years of age respectively. In the FAIR school cohorts, 798 (55.4\%), 775 (47.4\%) and $757(50.2 \%)$ children were seen at 6,11 and 15 years of age respectively. Recruitment of participants and data collection has been previously described in detail elsewhere $(8,10)$.

Children were clinically examined and skin prick tests (SPT) were performed to common food allergens (milk, egg, cod, sesame, wheat and peanut) and invited for food challenges when indicated. A positive SPT was defined by a mean wheal diameter of $3 \mathrm{~mm}$ or greater than the negative control (saline). SPT was conducted using standardised allergen reagents and methodology (ALK-Abello, Hørsholm, Denmark). Eczema was measured using the question "Has your child ever been diagnosed with eczema".

The labial dose was performed by rubbing the inner lower lip five times with a cooked sample of the allergenic food. In order to prevent irritant reactions, only plain foods were used (e.g. unsalted rather than salted peanuts). The challenge outcomes were graded according to the Isle of Wight David Hide Asthma and Allergy Research Centre protocols and later those of the PRACTALL guidelines (6), which were very similar.

For the 10 year follow-up of the FAIR birth cohort, ethical approval for the study was obtained from the NRES South Central - Southampton B Research Ethics Committee (ref: 10/H0504/11). For all other cohorts, ethical approval was obtained from the Isle of Wight, Portsmouth, and South East Hampshire Local Research Ethics Committee (ref: 09/01). 


\section{Results}

\section{Initial analyses}

The demographic data for the full cohorts has previously been published in a number of prevalence papers from the Isle of Wight (7-10). A total of 112 LFCs took place. This included four cases of children with positive LFCs, who did not proceed to an OFC, as parents declined to continue with the process. Therefore a total of 108 LFCs, followed up by an open food challenge, were included in the primary analysis, as indicated in Figure 1.

Of these 108 LFCs, a positive labial reaction was noted in nine challenges. All nine positive labial reactions resulted in a positive oral food challenge. Looking overall at the 108 food challenges, of which nine were preceded by a positive LFC, we have calculated a positive predictive value of $100 \%$ (95\% Cl 66.4-100\%), a negative predictive value of $72.7 \%$ (95\% Cl 68.8-76.3), with 100\% specificity (95\% Cl 94.9-100) and $25.0 \%$ sensitivity (95\% Cl 12.1-42.2).

The nine positive labial reactions, summarised in Table 1, were to sesame $(n=1)$, peanut $(n=3)$, prawn $(n=1)$ and egg $(n=4)$. The most common reaction to the labial dose was urticaria $(n=$ $3)$, followed by lip angioedema $(n=2)$. Other symptoms reported were rash and rhinorrhea. The dose reacted to during OFC varied from $250 \mathrm{mg}$ for peanut and egg (equating to $62.5 \mathrm{mg}$ peanut and $32.5 \mathrm{mg}$ egg protein respectively) to a maximum eliciting dose of $40 \mathrm{~g}$ prawn (equating to $1000 \mathrm{mg}$ prawn protein). The majority of participants reacted within the first 3 challenge doses (250 mg, 500mg and $1 \mathrm{~g}$ ), apart from the participant who reacted to $40 \mathrm{~g}$ of prawn.

Overall 44 children (40.7\%) reported a history of eczema. $55.6 \%(n=5)$ of those with a positive LFC had a history of eczema, compared to $39.8 \%(n=39)$ of those with a negative LFC, however this difference was not statistically significant (Fisher's exact test $p=0.483$ ). In terms of sensitization, $77.8 \%(n=7)$ of those with a positive LFC had a positive SPT, compared to $47.6 \%$ $(n=39)$ of those with a negative LFC, however this difference was not significantly different (Fisher's exact test $p=0.158$ ).

89

\section{Additional analyses}

We conducted additional analyses including the four cases of children with positive LFCs, who did not proceed to an OFC. Hypothetically if these four participants had a positive OFC result, the positive predictive value of the LFC would remain at 100\% (95\% Cl 75.29-100), as would the negative predictive value of $72.7 \%(95 \% \mathrm{Cl} 68.8-76.3)$ and the specificity of $100 \%(95 \% \mathrm{Cl} 95.01$ 100). However the sensitivity would increase to $32.5 \%$ (95\% Cl 18.57-49.13). Conversely if these four participants had a negative OFC result, the positive predictive value would decrease to $69.2 \%$ (95\% Cl 42.6-87.2), the negative predictive value would remain stable at $72.7 \%$ (95\% Cl 68.8 decrease to $94.7 \%(95 \% \mathrm{Cl} 87.1-98.6)$. 


\section{Discussion}

This study aimed to investigate whether a lip dose challenge can be used as a feasible alternative to a complete oral food challenge protocol in children. The data shows that a positive LFC was highly indicative of a positive oral food challenge, but a negative LFC does not rule out a positive oral food challenge. Although proportionately more children with a positive LFC had both eczema and a positive SPT to the food, compared to children with a negative LFC, the difference was not statistically significant. Due to the small number of children with a positive labial challenge, our analysis may be underpowered, so results should be interpreted with caution.

Unlike the study of Rance et al.,(1) where $4.5 \%$ of cases experienced systemic reactions, none of the children in this study experienced systemic reactions. This suggests, using our limited data, that a lip dose challenge is both safe and feasible. In this dataset, there were four cases of positive LFCs that did not proceed to a full OFC due to lack of parental consent to proceed. It was not possible to include these four cases in the statistical analysis, as we could not compare them against a valid OFC outcome and it is not possible to predict whether a systemic reaction would have occurred. Unfortunately there is limited published research available to compare our findings to. The only other study we could find referring to the usefulness of the labial challenge is that of Cantani et al. (3), who conducted 113 OFCs in children, the majority to cows' milk.

As ours was an observational birth cohort study, rather than a sample recruited from a clinical setting, we could not determine a priori which food allergens to investigate. We observed positive LFCs to only four different foods: sesame, peanut, shellfish and egg. Although cows' milk is the most common food allergen in young children in the United Kingdom $(8,11)$, the sample included in this study did not include any positive LFCs to cows' milk. This is probably because most CMA in the UK is non-IgE mediated as indicated in the UK cohort of the FAIR study in 2006 (12) and then confirmed by the of the EUROPREVALL study (13). Rance et al. (1) included LFCs to a wider variety of foods (mustard, cod, kiwi, snails, fennel and duck); which is reflective of the differing prevalence of food allergies between the UK and France.

The strengths of this study are that it included children of varied ages, using standardized protocols. The main limitation of the study is the small sample size of children with a positive LFC, which included only four food allergens. In conclusion our data, despite a very limited dataset, indicates that LFCs are feasible and safe. A positive LFC is highly indicative of a positive OFC, but a negative LFC does not rule out a positive OFC. This may have implications for implementation of food challenges in clinics with limited resources, particularly in terms of indicating which children are more likely to have a positive OFC.

Carina Venter PhD RD, Kate Maslin PhD RD, Jane Grundy RGH, Gillian Glasbey \& Tara Dean PhD. (School of Health Sciences and Social Work, University of Portsmouth \& David Hide Asthma and Allergy Centre, St. Mary's Hospital, Isle of Wight, UK). 
139 Acknowledgments: The authors would like to thank the families and participants of the FAIR

140 birth cohort and school studies.

141

142 Funding: The UK Food Standards Agency (FSA) funded years 1-3 of the FAIR study (ref T0703).

143 Carina Venter was funded by a National Institute for Health Research Postdoctorate research

144 award for the 10 year FAIR study follow up. The researchers acted independent of the funders 145 (FSA UK and NIHR UK).

146

147 Conflicts of interest: The authors declare no conflicts of interest.

148 


\section{References}

1. Rance F, Dutau G. Labial food challenge in children with food allergy. Pediatr Allergy Immunol. 1997;8(1):41-4.

2. Monteret-Vautrin D. Advances in Allergology and Clinical Immunology. In: Godard P, Bousquet $\mathrm{J}$, Michel F, editors. The proceedings of the plenary sessions and the afternoon symposia of the the XVth European Congress of Allergology and Clinical Immunology Paris, France. The Parthenon Publishing Group; 1992. p. 473-83.

3. Cantani A. Letter to the Editor re "Labial food challenge in children with food allergy." Pediatr Allergy Immunol. 1998;9:103.

4. Meglio P, Giampietro P, Farinella F, Cantani A, Businco L. Personal experience in the diagnostic procedures in children with atopic dermatitis and food allergy. Allergy. 1989;44(S9):165-73.

5. Bindslev-Jensen C, Ballmer-Welser BK, Bengtsson U, Blanco C, Ebner C, Hourihane J, et al. Standardization of food challenges in patients with immediate reactions to foods Position paper from the European Academy of Allergology and Clinical Immunology. Allergy Eur J Allergy Clin Immunol. 2004;59(7):690-7.

6. Sampson HA, Gerth Van Wijk R, Bindslev-Jensen C, Sicherer S, Teuber SS, Burks AW, et al. Standardizing double-blind, placebo-controlled oral food challenges: American Academy of Allergy, Asthma \& Immunology-European Academy of Allergy and Clinical Immunology PRACTALL consensus report. J Allergy Clin Immunol [Internet]. 2012;130(6):1260-74. Available from: http://dx.doi.org/10.1016/j.jaci.2012.10.017

7. Venter C, Pereira B, Grundy J, Clayton CB, Arshad SH, Dean T. Prevalence of sensitization reported and objectively assessed food hypersensitivity amongst six-year-old children: A population-based study. Pediatr Allergy Immunol. 2006;17(5):356-63.

8. Venter C, Pereira B, Voigt K, Grundy J, Clayton CB, Higgins B, et al. Prevalence and cumulative incidence of food hypersensitivity in the first 3 years of life. Allergy. 2008;63(7):354-9.

9. Venter C, Patil V, Grundy J, Glasbey G, Twisleton R, Arshad SH, et al. Prevalence and cumulative incidence of food hypersensitivity in the first 10 years of life. Submitted. 2015;

10. Pereira B, Venter C, Grundy J, Clayton CB, Arshad SH, Dean T. Prevalence of sensitization to food allergens, reported adverse reaction to foods, food avoidance, and food hypersensitivity among teenagers. J Allergy Clin Immunol. 2005;116(4):884-92.

11. Grimshaw KEC, Bryant T, Oliver EM, Martin J, Maskell J, Kemp T, et al. Incidence and risk factors for food hypersensitivity in UK infants : results from a birth cohort study. Clin Transl Allergy. 2016;1-13.

12. Venter C, Pereira B, Grundy J, Clayton CB, Roberts G, Higgins B, et al. Incidence of parentally reported and clinically diagnosed food hypersensitivity in the first year of life. $J$ 
186

187

188

189

190

191
Allergy Clin Immunol. 2006;117:1118-24.

13. Schoemaker AA, Sprikkelman AB, Grimshaw KE, Roberts G, Grabenhenrich L, Rosenfeld $\mathrm{L}$, et al. Incidence and natural history of challenge-proven cow's milk allergy in European children - EuroPrevall birth cohort. Allergy [Internet]. 2015;70(8):963-72. Available from: http://doi.wiley.com/10.1111/all.12630 
Table 1 Summary of challenges undertaken at different ages

\begin{tabular}{|c|c|c|c|c|c|c|c|c|c|}
\hline Age & Sex & $\begin{array}{c}\text { Foods } \\
\text { challenged }\end{array}$ & $\begin{array}{c}\text { Number } \\
\text { participants } \\
\text { with } \\
\text { eczema }\end{array}$ & $\begin{array}{l}\text { Number } \\
\text { of } \\
\text { positive } \\
\text { SPTs }\end{array}$ & $\begin{array}{c}\text { Number of } \\
\text { LFCs }\end{array}$ & $\begin{array}{c}\text { Number of } \\
\text { positive } \\
\text { LFCs }\end{array}$ & $\begin{array}{c}\text { Number of } \\
\text { positive } \\
\text { OFC } \\
\text { following } \\
\text { positive LFC }\end{array}$ & $\begin{array}{c}\text { Number } \\
\text { of } \\
\text { negative } \\
\text { LFCs }\end{array}$ & $\begin{array}{l}\text { OFC outcome } \\
\text { following } \\
\text { negative LFC }\end{array}$ \\
\hline 1 year & $\begin{array}{c}27 \text { male } \\
13 \text { female }\end{array}$ & $\begin{array}{l}\text { Milk, egg, cod, } \\
\text { wheat, corn, } \\
\text { tomato, citrus } \\
\text { fruit, strawberry }\end{array}$ & 16 & 13 & 40 & 3 (egg) & 3 & 37 & $\begin{array}{c}10 \text { positive } \\
27 \text { negative }\end{array}$ \\
\hline 2 years & $\begin{array}{c}6 \text { male } \\
4 \text { female }\end{array}$ & $\begin{array}{c}\text { Milk, egg, } \\
\text { wheat, citrus } \\
\text { fruit }\end{array}$ & 9 & 4 & 10 & 1 (egg) & 1 & 9 & $\begin{array}{l}2 \text { positive } \\
7 \text { negative }\end{array}$ \\
\hline 3 years & $\begin{array}{l}14 \text { male } \\
8 \text { female }\end{array}$ & $\begin{array}{l}\text { Egg, cod, corn, } \\
\text { peanut, sesame, } \\
\text { kiwi, pineapple }\end{array}$ & 11 & 10 & 22 & 1 (peanut) & 1 & 21 & $\begin{array}{c}4 \text { positive } \\
17 \text { negative }\end{array}$ \\
\hline 6 years & $\begin{array}{c}5 \text { male } \\
4 \text { female }\end{array}$ & $\begin{array}{c}\text { Sesame, } \\
\text { banana, peanut, } \\
\text { cod, almond }\end{array}$ & 3 & 9 & 9 & 0 & 0 & 9 & $\begin{array}{l}2 \text { positive } \\
7 \text { negative }\end{array}$ \\
\hline $\begin{array}{c}10 \\
\text { years }\end{array}$ & $\begin{array}{c}6 \text { male } \\
2 \text { female }\end{array}$ & $\begin{array}{l}\text { Peanut, egg, } \\
\text { brazil nut }\end{array}$ & 3 & 6 & 8 & 0 & 0 & 8 & $\begin{array}{l}4 \text { positive } \\
4 \text { negative }\end{array}$ \\
\hline $\begin{array}{c}11 \\
\text { years }\end{array}$ & $\begin{array}{c}4 \text { male } \\
7 \text { female }\end{array}$ & $\begin{array}{c}\text { Peanut, almond, } \\
\text { sesame, soy, } \\
\text { cheese }\end{array}$ & 1 & 8 & 11 & 2 (peanut) & 2 & 9 & $\begin{array}{l}2 \text { positive } \\
7 \text { negative }\end{array}$ \\
\hline $\begin{array}{c}15 \\
\text { years }\end{array}$ & $\begin{array}{c}5 \text { male } \\
3 \text { female }\end{array}$ & $\begin{array}{l}\text { Milk, fruit, soya, } \\
\text { hazelnut, prawn, } \\
\text { sesame, raisin }\end{array}$ & 1 & 3 & 8 & $\begin{array}{l}2 \text { (1 child } \\
\text { sesame \& } \\
1 \text { child } \\
\text { prawn) }\end{array}$ & 2 & 6 & $\begin{array}{l}3 \text { positive } \\
3 \text { negative }\end{array}$ \\
\hline Total & $\begin{array}{c}67 \text { male } \\
41 \text { female }\end{array}$ & & 71 & 53 & 108 & 9 & 9 & 99 & $\begin{array}{l}27 \text { positive } \\
72 \text { negative }\end{array}$ \\
\hline
\end{tabular}

SPT: Skin prick test OFC: Oral food challenge. LFC: Labial food challenge. 
Figure 1. Flowchart outlining number of participants with positve and negative results

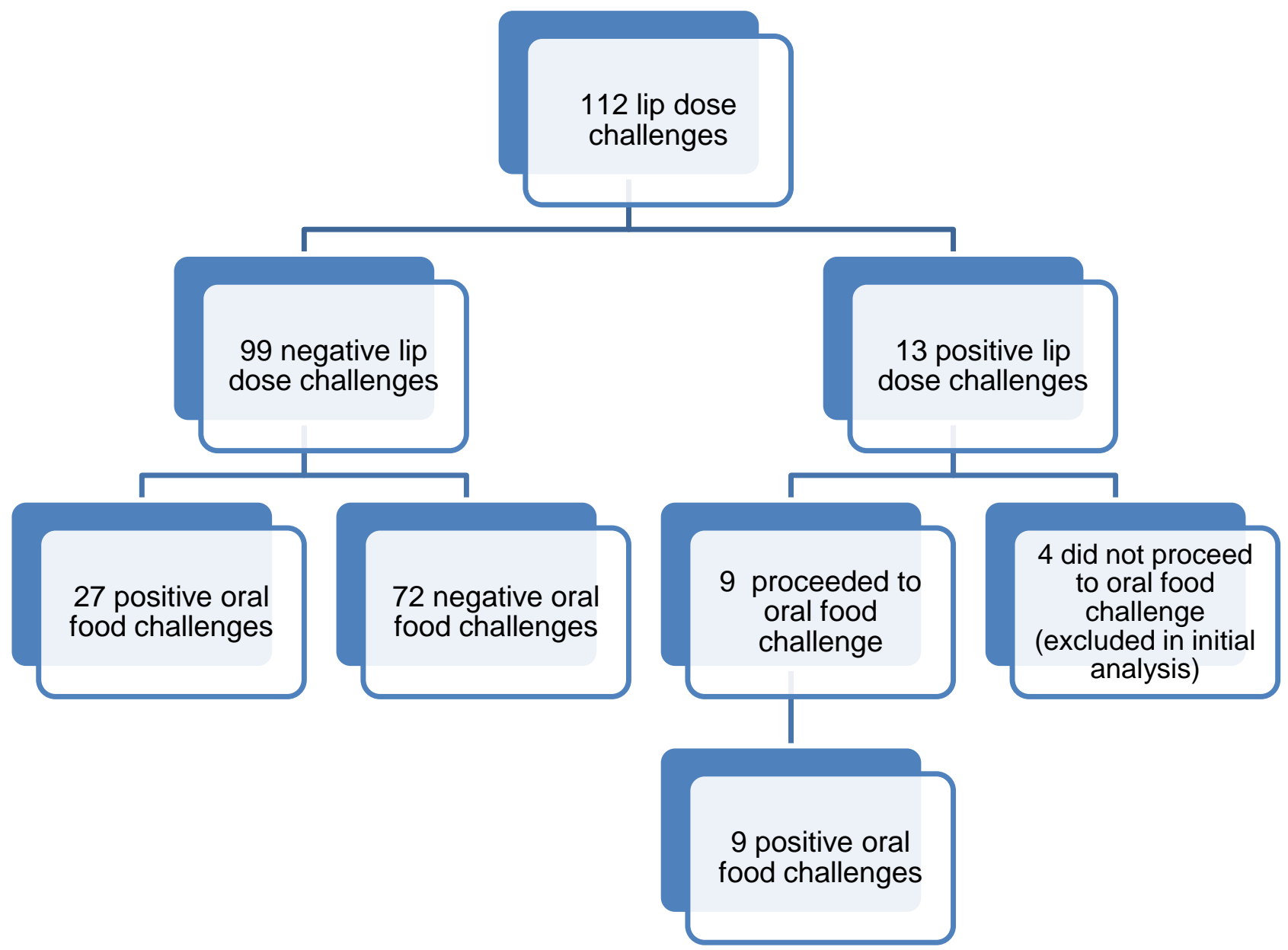

